\title{
Agronomic performance of RPR fertiliser in a grazed pasture
}

\author{
AgResearch, Winchmore Research Station, Private Bag. Ashburton
}

\begin{abstract}
The effectiveness of Sechura RPR (SPR) plus sulphur (S) as a development and maintenance fertiliser was compared with superphosphate (SSP) on an imigated grazed pasture. In 1980, SSP or SPR plus $\mathrm{S}$ was applied at $71 \mathrm{~kg} / \mathrm{ha}$ phosphorus $(\mathrm{P})$ to pastures that had not received fertiliser for 22 years, but had been recently over-drilled with ryegrass and white clover. Annual maintenance rates of $250 \mathrm{~kg}$ SSP/ha and $175 \mathrm{~kg}$ SPR/ha plus $\mathrm{S}$, (supplying $22 \mathrm{~kg} \mathrm{P} / \mathrm{ha}$ and $27 \mathrm{~kg} \mathrm{~S} / \mathrm{ha}$ ), were applied from 1981 to 1992. In the first year the SSP treatment restored pasture production to near optimal level and this level was maintained over subsequent years with annual topdressings. In contrast, the SPR plus S treatment did not restore pasture production until the third year. In the first two years production from this treatment was only $69 \%$ and $88 \%$, respectively, of the $250 \mathrm{~kg} / \mathrm{ha} / \mathrm{year}$ SSP treatment. From year 3, annual applications of SPR plus $S$ maintained pasture production. In the first 3 years $\mathrm{P}$ concentrations of pasture topdressed with SPR were lower than those of pastures topdressed with SSP. Herbage S concentrations were adequate on both fertiliser treatments. Soil Olsen P levels rose quickly in the first year after the initial application of SSP then decreased to the same level as the SPR plus S treatment. Olsen P levels have been rising steadily since 1983 , from both forms of $\mathrm{P}$, indicating that $22 \mathrm{~kg} \mathrm{P} / \mathrm{ha} /$ year is above maintenance for this site.
\end{abstract}

Keywords development fertiliser, irrigated pasture, maintenance fertiliser, Sechura reactive phosphate rock, superphosphate

\section{Introduction}

Since the early 1980s there have beennumerous studies investigating the effectiveness of reactive phosphate rock (RPR) as an alternative to superphosphate (SSP) in either a development (Mackay et al. 1984; Wilson \& Jordan 1989. Mackay 1990), or a maintenance situation (Sinclair et al. 1990; Mackay 1990; Smith et al. 1991).

Published work has highlighted two features: i) Pasture receiving RPR often takes longer than SSP to reach optimum yields (lag period); and ii) Soil $\mathbf{p H}$ and annual rainfall are major factors influencing the effectiveness of RPR.

However, none of the published work has studied the effectiveness of RPR over periods longer than 6 years. In 1980, two treatments were incorporated into the long term phosphate trial at Winchmore Research Station (Rickard \& McBride 1987; Nguyen et al. 1989). to measure the effectiveness of RPR compared with SSP as a development and then a maintenance fertiliser on grazed, irrigated pasture on a Lismore stony silt loam.

\section{Methods}

\section{Trial site}

The trial site was first established in 1952 to evaluate the effect of SSP rates (nil. 188, 376, 576, 376 (split spring/ autumn) $\mathrm{kg} / \mathrm{ha} / \mathrm{year}$ ) on irrigated pasture production under grazing. In 1958 after 6 years of SSP applications, the 376 and 564 treatments were discontinued and the residual effects measured. By 1980 , production from these two treatments was only $48 \%$ of that from SSP applied at $376 \mathrm{~kg} / \mathrm{ha} / \mathrm{year}$. Soil Olsen phosphorus (P) levels $(8 \mu \mathrm{g} / \mathrm{ml})$ and sulphate sulphur (S) levels (4 ppm) were low compared with $20 \mu \mathrm{g} \mathrm{P} / \mathrm{ml}$ and $6 \mathrm{ppm} \mathrm{S}$ on the continuous SSP treatment applied at $376 \mathrm{~kg} / \mathrm{ha}$. Initial soil pH was 6.0 in 1980 and has declined to5.7 in 1991.

Trial design

In 1980, it was calculated that $70 \mathrm{~kg} \mathrm{P} / \mathrm{ha}$ was requirzd to increase the level of soil $\mathrm{P}$ in the $0-75 \mathrm{~mm}$ soil depth to a level intermediate between those on SSP applied at 188 and $376 \mathrm{~kg} / \mathrm{ha} / \mathrm{year}$. The sward on the residual treatment areas was broken up by heavy trampling with sheep and direct drilled with ryegrass $(20 \mathrm{~kg} / \mathrm{ha})$ and white clover $(3 \mathrm{~kg} / \mathrm{ha})$ in early August 1980 .

In September 1980,730 kg/ha of either SSP (supplying $60 \mathrm{~kg} \mathrm{P}$ ) or SPR (supplying $71 \mathrm{~kg} \mathrm{P}$ ) plus sulphur was applied. Each treatment was allocated 2 replicates of the old residual treatments. After further product testing more SSP was applied in early November 1980 to 
balance the total amount of $\mathrm{P}$. This, however, resulted in more $\mathrm{S}$ being applied to the SSP $(91 \mathrm{~kg} / \mathrm{ha})$ than the SPR (5 $1 \mathrm{~kg} / \mathrm{ha}$ ) treatment in the fiit year.

From 1981 SSP was applied annually at $250 \mathrm{~kg} / \mathrm{ha}$ and SPR plus $S$ at $175 \mathrm{~kg} / \mathrm{ha}$. Both forms of $\mathrm{P}$ supplied equal amounts of $P(22 \mathrm{~kg} / \mathrm{ha})$ and $\mathbf{S}(27 \mathrm{~kg} / \mathrm{ha})$.

Each treatment was grazed by a'separate flock of dry ewes to ensure no fertility transfer between treatments. The stocking rate on each treatment was adjusted so that $80 \%$ of the pasture was utilised.

All treatments were irrigated simultaneously by the border strip method whenever the soil moisture in the 0 $100 \mathrm{~mm}$ depth dropped to $25 \%$ available soil moisture. Over the trial period annual rainfall averaged $650 \mathrm{~mm}$ and an average of 4 irrigations per year were applied. Therefore, with irrigation, the soil was kept relatively moist throughout, and would exceed the minimum 800 $\mathrm{mm}$ rainfall criteria established by Sinclair et al. (1990) for effective dissolution of RPR.

\section{Measurements}

Pasture production was measured by an enclosure technique (Lynch 1966) with a sampling area of $5 \mathbf{m}^{\mathbf{2}}$ over 2 enclosures. An average of 8 harvests were made per year. At each harvest, $\mathrm{P}$ and $\mathrm{S}$ concentrations were measured on the mixed sward andbotanical dissections were carriedout. Soil samples $(0-75 \mathrm{~mm})$ were collected from each plot 4 times per year for soil $\mathrm{P}$ and $\mathrm{S}$ analysis.

\section{Treatment fertilisers}

\section{Superphosphate}

The citric soluble $\mathrm{P}$ fraction of the SSP applied averaged 5.2 in $1980 / 81$ and increased to average 8.3 in $1989 / 90$.

\section{Sechura RPR}

The initial application in September 1980 was ground powdered SPR pelleted using gypsum as a binding agent. This had a composition of $9.4 \%$ total $\mathrm{P}$ and $7.0 \%$ sulphate S. Particle size analysis of this product showed that $55 \%$ was less than $0.075 \mathrm{~mm}$ whilst normally "as received"' SPR would contain only $2-3 \%$ less than 0.075 mm. From 1981 to 1983, SPR /elemental S granules were made from "as received" SPR mixed with molten S. The resulting product had similar particle size to the original SPR and a mean P content of $11.2 \%$ and S content of $13.2 \%$.The $S$ in this form was probably less soluble than the gypsum. Since 1984 "as received" SPR plus elemental $S$ (sieved to $<2 \mathrm{~mm}$ ) has been applied.

\section{Results and discussion}

In the first 2 years, pasture production from SPR/S was less than from SSP and this period has been termed the developmentphase (Table 1 ,Fig. 1). From 1982 to 3992 production from both fertilisers has been similar and this period has been termed the maintenance phase.

Table 1 Annual pasture production (t DWha) from SSP and SPR.

\begin{tabular}{cccccc}
\hline Year & Control & \multicolumn{5}{c}{ 250 Super } & Sechura/S & 376 Super & LSD(5\%) \\
\hline $80 / 81$ & 4.3 & 9.7 & 6.7 & 11.4 & 2.2 \\
$81 / 82$ & 4.1 & 10.0 & 8.6 & 10.2 & 1.4 \\
$82 / 83$ & 3.5 & 9.4 & 9.8 & 11.1 & 1.5 \\
$83 / 84$ & 3.4 & 10.1 & 10.9 & 10.6 & 1.6 \\
$84 / 85$ & 3.3 & 9.4 & 10.1 & 9.3 & 1.9 \\
$85 / 86$ & 4.1 & 11.9 & 12.5 & 12.2 & 1.6 \\
$86 / 87$ & 5.3 & 11.8 & 12.5 & 13.8 & 2.6 \\
$87 / 88$ & 4.0 & 11.3 & 9.9 & 11.5 & 1.7 \\
$88 / 89$ & 5.7 & 12.0 & 11.6 & 11.7 & 1.4 \\
$89 / 90$ & 6.7 & 12.4 & 12.6 & 11.6 & 1.5 \\
$90 / 91$ & 5.4 & 11.0 & 11.2 & 11.6 & 1.8 \\
$91 / 92$ & 5.3 & 10.9 & 10.6 & 12.0 & 1.6 \\
\hline
\end{tabular}

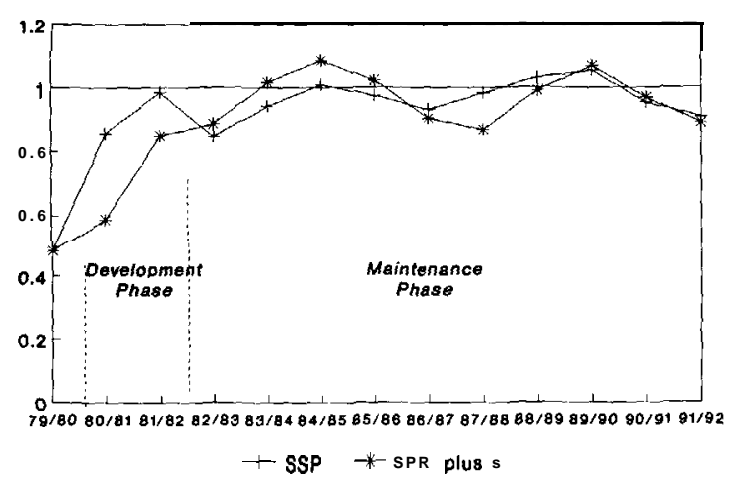

Figure 1 Pasture production from SSP or SPR relative to SSP applied at $376 \mathrm{~kg} / \mathrm{ha}$ per year.

\section{Development phase}

In the first two years pasture production from the applications of SSP was not significantly different from the $376 \mathrm{~kg} \mathrm{SSP/hatreatment.} \mathrm{Most} \mathrm{of} \mathrm{the} \mathrm{reduction} \mathrm{in} \mathrm{the}$ first year (1980/81) occurred in September and October. In contrast, production from SPR/S was only 69\% and $88 \%$ of the 250 SSP treatment in years 1 and 2 respectively. These differences were significant at the 5\% level of probability. The lag period of 2 years was longer than that reported by Wilson \& Jordan (1989) for SPR, and Mackay (1990) for North Carolina Phosphate Rock (NCPR) in development situations. 
SPR particle size. initial rate of application, SSP quality, and soil $\mathbf{p H}$ would have influenced the length of the lag period between SPR and SSP on this site.

The initial application of ground SPR could have been expected to increase the dissolution rate but the effect of thefmerparticlesixemayhavebeennegatedby the presence of gypsum. Other unreported work at Winchmore over 6 years, showed that there was no agronomic difference between ground SPR (with gypsum) as applied initially in the reported trial and "as received'* SPR (plus elemental sulphur).

This unreported work did show, however, that the lag period was reduced from 2 to 1 year when $60 \mathrm{~kg}$ P/ ha was applied compared with $20 \mathrm{~kg}$ P/ha. This would suggest that the $70 \mathrm{~kg} P / \mathrm{ha}$ applied in the first year of this trial would have reduced the lag period compared with lower amounts of $P$.

During the development phase the quality of SSP used was low $(5.2 \%$ citric soluble P). Pasture production from the SSP treatments may have been lower than what could be expected from the currently manufactured higher quality SSP, thus creating a shorter lag period.

Clover production in the first year was significantly higher on the 250 SSP treatment (37\% of sward), compared with the SPR/S treatment (24\%). This was in contrast to the trend in clover content found by Mackay (1990).

\section{Maintenance phase}

From spring $1982 / 83$ to $1991 / 92$ there was nosignificant difference in pasture production between SSP and SPR $\mathrm{S}$. This was the same finding as on the Winchmore irrigated site (Smith et al. 1991) which showed that applying $20 \mathrm{~kg}$ P/ha per year as SPR or SSP maintained pasture production at similar levels,

Other work (Sinclair et al. 1992) showed that SPR can supply Mo to soils that are Mo deficient but this response pattern was not evident in this trial.

\section{Herbage $\mathbf{P}$ concentration}

The initial application of SSP increased the herbage $P$ concentration from $0.25 \%$ to $0.33 \%$ in the first year (Table 2). This was close to the optimum range $(0.35 \%$ - $0.40 \%)$ recommended by Comforth \& Sinclair (1984). In contrast, applying an equivalent amount of $\mathbf{P}$ as SPR raised the herbage $\mathbf{P}$ concentration only slightly in the first 2 years. Mackay (1990) showed on both the mowing and grazing trials there was no difference in herbage $P$ concentrations in the first year between SSP andNCPR.

By year 4 , herbage $P$ concentrations were similar for both the SSPandSPR/S treatments and both have tended to increase with time.
Table 2 Herbage $P$ concentrations (\%.P) from SSP and SPR applications.

\begin{tabular}{|c|c|c|c|}
\hline \multicolumn{2}{|c|}{$\begin{array}{c}250 \\
\text { Superphosphate }\end{array}$} & Sochura/S & $\begin{array}{c}376 \\
\text { Superphosphate }\end{array}$ \\
\hline 3 Yr pre av. & 0.25 & 0.25 & 0.43 \\
\hline $80 / 81$ & 0.33 & 0.28 & 0.42 \\
\hline $81 / 82$ & 0.32 & 0.28 & 0.43 \\
\hline $82 / 83$ & 0.35 & 0.31 & 0.43 \\
\hline $83 / 84$ & 0.37 & 0.36 & 0.47 \\
\hline $84 / 85$ & 0.33 & 0.33 & 0.43 \\
\hline $85 / 88$ & 0.38 & 0.37 & 0.47 \\
\hline $86 / 87$ & 0.41 & 0.41 & 0.50 \\
\hline
\end{tabular}

\section{Herbage $S$ concentrations}

From year 1 herbage $\mathbf{S}$ levels of both treatments were above $0.3 \%$ which is higher than the required optimum $(0.27 \%-0.32 \% \mathrm{~S})$ levels reported by Cornforth and Sinclair (1984). These levels have been maintained.

\section{Soil $\mathbf{P}$ status}

The initial application of SSP quickly raised the Olsen P level from 8 to $15 \mu \mathrm{g} / \mathrm{ml}$ in early November 1980 before the second application of SSP (Fig. 2). By July 1981 the Olsen Plevel had decreased to $6 \mu \mathrm{g} / \mathrm{ml}$; one unit above SPR which had decreased slightly since topdressing.

Since about 1983 there has been an upward trend in the average soil Olsen $\mathbf{P}$ levels on both treatments, indicating that $22 \mathrm{~kg} \mathrm{P} /$ ha/year is above maintenance for this site.

\section{Conclusions}

1. The application of $71 \mathrm{~kg} \mathrm{P} / \mathrm{ha}$ and $91 \mathrm{~kg} \mathrm{~S} / \mathrm{ha}$ as SSP in 1980 to irrigated pasture that had not received fertiliser for 22 years restored pasture production to optimum levels within 12 months. This level of production was maintained with $250 \mathrm{~kg}$ SSP/ha/year from 1981-1992.

2. In contrast, applying $71 \mathrm{~kg} \mathbf{P} /$ ha as $\mathbf{S} P R$ and 51 $\mathrm{kg} \mathbf{S} /$ ha resulted in a 2 -year lag period before pasture production was at an optimal level.

3. In subsequent years (1983-1992). SPR/S was as effective as SSP in maintaining optimum pasture production.

4. Over the period of the trial (1980-1992) soil Olsen $\mathbf{P}$ levels have steadily increased on both treatments, indicating that the amount of phosphorus applied each year is above that required to maintain soil $\mathrm{P}$ levels at this site. 


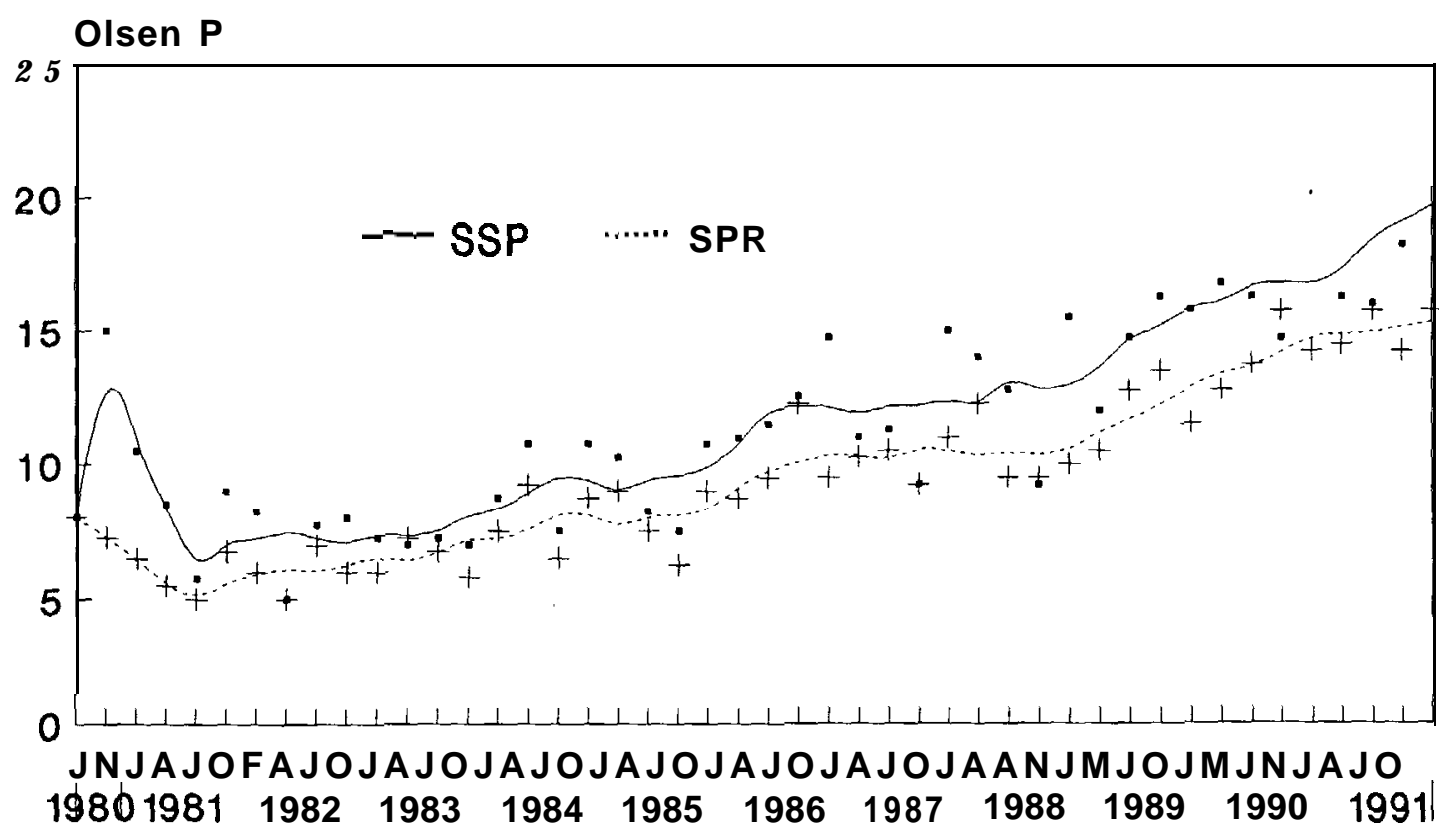

Flgure 2 Soil Olsen P levels from SSP or SPR Lines smoothed.

\section{ACKNOWLEDGEMENTS}

Technical staff at Wiichmore over a number of years; in particular GN. Green and G.C. Hayes.

\section{REFERENCES}

Cornforth, I.S.; Sinclair, A.G. 1984. Fertiliser recommendations for pastures and crops in New Zealand. Ministry of Agriculture and Fisheries, Wellington, New Zealand.

Lynch, P.B. 1966: Conduct of field experiments. Bulletin399. New Zealand Department of Agriculture. $154 \mathrm{pp}$.

Mackay, A.D.; Gregg, P.E.H.; Syers, J.K. 1984. Field evaluation of Chatham Rise phosphorite as a phosphatic fertiliser for pasture. New Zealand Journal of Agricultural Research. 27: 65-82.

Mackay, A.D. 1990. Comparison of phosphate fertilisers in a grazed hill country pasture. Proceedings of the New Zealand GrasslandAssociation 51:97100.

Nguyen, M.L.; Rickard, D.S.; McBride,S.D. 1989. Pasture production and changes in phosphorus and sulphur status in irrigated pastures receiving long. term applications of superphosphate fertiliser. New Zealand Journal of Agricultural Research 32: 245-262.

Rickard, D.S.; McBride, S.D. 1987. Long term applica- tions and residual effects of superphosphate and effects of reactive phosphate rock on irrigated pasture. WinchmoreIrrigation Research Station technical report No. 22. New Zealand Ministry of Agriculture and Fisheries.

Sinclair, A.G.; Dyson, C.B.; Shannon, P.W. 1990.The long-term effectiveness of reactive phosphate rock as a phosphate fertiliser for New Zealand pastures. Proceedings of the New Zealand Grassland Association 51: 101-104.

Sinclair, A.G.; Johnstone, P.D.; Smith, L.C.; O'Conner, M.B.; Shannon, P.W.; Nguyen, L.; Risk, W.D.; Morton, J.D.; Roberts A.H. 1992. Comparative performance of reactive phosphate rocks and triple super-phosphate as phosphatic fertilizers for the maintenance of permanent grass/ clover pastures. ( In Press).

Smith,L.C.; Johnstone,P.D.; Sinclair, A.G.; Shannon, P.W.; O'Connor, M.B.; Percival, N; Roberts, A.H.; Smith, R.G.; Mansell, G.; Morton, J.D.; Nguyen, L.; Dyson, C.B. and Risk, W.H. 1990 \& 1991. Final report on the MAF "National Series" forms of fertiliser trials. Ministry of Agriculture \& Fisheries, Wellington, New Zealand. Wilson, H.G.; Jordan, W.J. 1989. Dynamics and economics of pasture production responses to a representative range of phosphorus and sulphur fertilisers. Proceedings of the New Zealand Grassland Association 50: 145-150. 